\title{
Optimization Design of Pile Supported Embankment on Soft Soil Ground
}

\author{
J.B. Zhao \\ Corresponding author, Engineer, Key Laboratory of \\ Highway Construction and Maintenance Technology in \\ Loess Region \\ Shanxi Transportation Research Institute \\ Taiyuan, China
}

\author{
J. Zhang \\ Engineer, Key Laboratory of Highway Construction and \\ Maintenance Technology in Loess Region \\ Shanxi Transportation Research Institute \\ Taiyuan, China
}

\begin{abstract}
To optimization design of pile supported embankment on the soft soil ground, the numerical simulation is carried out to investigate the performance of pile supported embankment. The four embankments investigated include supported by piles only case, supported by caped piles only case, supported by both piles and geosynthetic case and supported by both caped piles and geosynthetic case. Finally, to further investigate the performance of pile supported embankment, five key influencing factors are chosen for parametric study. The results show that the pile cap and geosynthetic can reduce the settlement, but the effect of geosynthetic is not obvious. The effect of this transferring load of the pile caps is larger than the geosynthetic, and the effect of pile caps is larger than the geosynthetic. Moreover, the effect of geosynthetic will be weakened as the case with the pile caps.
\end{abstract}

Keywords-pile supported embankment; geosynthetic; soft soil; optimization design

\section{INTRODUCTION}

A number of research activities on this application have been performed in the past several years. The studies include theoretical analyses, laboratory tests, full scale tests, field monitoring, and numerical modeling. Terzaghi(1936)[1]proposed a theoretical model to describe the soil arching phenomenon and provided an equation to calculate vertical stress after performing a series of trapdoor tests. Giroud et al. (1990)[2] assumed that the deformed membrane sheet had a circular shape and proposed an analytical solution to account for the membrane effect. Chen et al. (2004) [3]modified the three-dimensional soil arching model and obtained a formula for calculating the load sharing ratio of piles. Chew et al. (2004)[4] built a full scale test pit in Malaysia to investigate the load transfer mechanism of GRPS embankments, utilized load cells and linear variable differential transducers to monitor the deflection and the load transfer. Han and Gabr (2002) [5]fulfilled a two-dimensional axisymmetric numerical modeling to analyses the influence of various factors (including height of fill, tensile stiffness of geosynthetic, and elastic modulus of pile) on settlement, tension in reinforcement, and soil arching ratio in a unit cell model. Abusharar et al. (2009) [1]conducted a series of two-dimensional (2D) numerical modelings to analyses the consolidation behavior of a multicolumn supported embankment, the settlement, horizontal displacement, differential settlement, column axial force, and the development and dissipation of excess pore pressure are presented and discussed in detail. Zheng et al. (2009) [6]studied the performance of embankments on soft ground with different reinforcing conditions and discussed the influencing factors.

But these are many different types about pile supported embankments in China and some disputes of research activities. Liu et al. (2008) fulfilled a numerical modeling base on a typical soft foundation segment treated with dry jet mixing (DJM) piles in the Shanghai-Nanjing expressway widening project and the results show that laying geogrid over the soft foundation treated with caped piles has not distinct improvement on total and differential settlements. Yang and Huang (2008) reported finite element analyses showed that the DJM piles combined with geogrid improvement method is more effective than the single DJM pile method. Lian et al. (2009)[7] carried out field tests which reinforced with both caped piles and geosynthetic, and proposed the load transfer ability of geogrid is better than the soil arch.

In the present study, to optimization design of this technology, coupled mechanical and hydraulic numerical analysis was conducted under two-dimensional conditions to investigate four cases about pile supported embankments are as follow: (1) G1P1 case: an embankment supported by piles only, (2) G2P1 case: an embankment supported by both piles and geosynthetic, (3) G1P2 case: an embankment supported by caped piles only, (4) G2P2 case: an embankment supported by both caped piles and geosynthetic.

\section{NUMERICAL ANALYSIS}

\section{A. Problem Description}

The selected embankment was $6 \mathrm{~m}$ in height and $24 \mathrm{~m}$ in crest width. A sand cushion, $0.5 \mathrm{~m}$ thick, was placed over the saturated soft clay. The soil profile consists of two layers as follows: 16 mof soft soil, $16 \mathrm{~m}$ of firmsoil.The length of the piles was $16 \mathrm{~m}$ and the pile tips embedded the firm soil. The diameter of pile was $0.5 \mathrm{~m}$ and the typical center-to center spacing between two piles was $3.5 \mathrm{~m}$. One layer of woven geosynthetic was placed over the piles. The ground water table was taken at the ground surface.The construction process of the cushion and the embankment consisted of seven phases. The first phase was the construction process of the cushion over 5 days. Each phase of the others added $1 \mathrm{~m}$ of height over 10 days. With this project background, a two-dimensional finite 
element model was established. The dimension and profile of the cross-section of the model is shown in Fig. I.

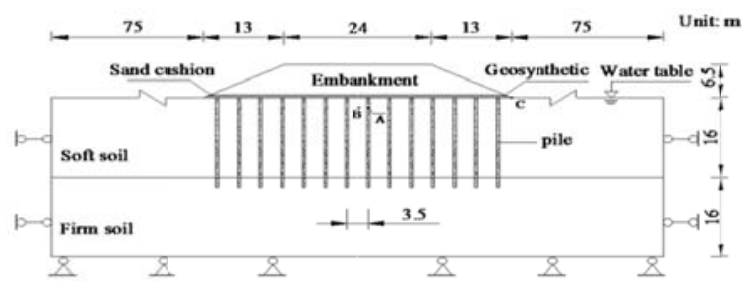

FIGURE I. CROSS-SECTION OF GRPS (G2P1) EMBANKMENT

\section{B. Finite Element Analysis}

A two-dimensional finite element program, namely Plaxis, was used for the numerical modeling. The size of the modeled domain was determined on the basis oftrial calculations, during which the mesh was progressively refinedand its boundaries extended until the stresses and deformations at thehighlystressed zones have sufficiently stabilized. To reduced error, the lateral boundaries were extendedto $75 \mathrm{~m}$ on each side of the embankment, and the lower boundary was extended to $12 \mathrm{~m}$ on the bottom of the piles. The lower boundarywas assumed to be completelyrigid and impermeable. The nodes on the two verticalboundaries werefixed against horizontal movement but allowedto move freely in the vertical direction. The soil and the piles domains were represented by 15-noded triangular elements and the geosynthetic layer was represented by 5noded geogrid elements. Slippage between soil and pile (or geosynthetic) was modeled by interface elements. The average rate of simulated construction was $0.1 \mathrm{~m} / \mathrm{d}$. As Fig. II shown was the finite element mesh of the GRPS (G2P1) embankment.

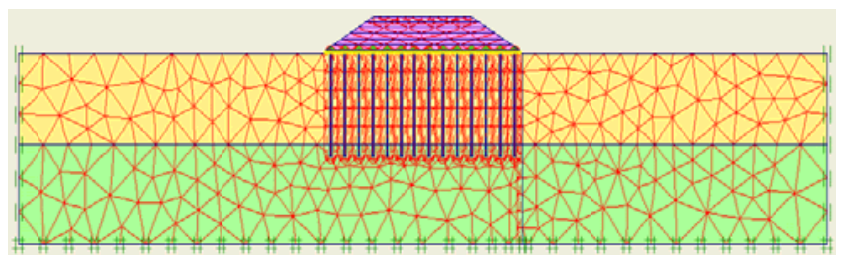

FIGURE II. FINITE ELEMENT MESH OF GRPS(G2P1) EMBANKMENT

\section{Material Model and Parameters}

The elastic-plastic model with the Mohr-Coulomb Model failure criterion was used for the embankment fill, sand cushion, soft soil and firm soil. The geosynthetic wasrepresented by a geogrid element in Plaxis. It is flexible elastic elements thatrepresent sheet of fabric in out of plane direction and can sustain tensile forces but notcompression. A linear elastic model was applied to the piles and pile caps. The material properties of the soil, sand cushion and embankment fill in the finite element model were obtained from the in-situ and laboratory tests. The material properties of the embankment, sand cushion, soft soil, firm soil, pile, pile cap, and geosynthetic are presented in Table I.

TABLE I. MATERIAL PROPERTIES IN THE NUMERICAL MODEL

\begin{tabular}{ccccccc}
\hline Parameter & Unit & $\begin{array}{c}\text { Embank- } \\
\text { ment }\end{array}$ & $\begin{array}{c}\text { Sand } \\
\text { cushi } \\
\text { mon }\end{array}$ & Soft soil & Firm soil & pile \\
\hline Material model & - & $\mathrm{M}-\mathrm{C}$ & $\mathrm{M}-\mathrm{C}$ & $\mathrm{M}-\mathrm{C}$ & $\mathrm{M}-\mathrm{C}$ & elastic \\
Sat. unit weight & $\mathrm{kN} / \mathrm{m}$ & 20.4 & 21.3 & 19.5 & 20.2 & - \\
Horizontal permeability & $\mathrm{m} / \mathrm{d}$ & - & 1.0 & $8.630^{*} 10^{-4}$ & $8.630^{*} 10^{-4}$ & - \\
Vertical permeability & $\mathrm{m} / \mathrm{d}$ & - & 1.0 & $1.06 * 10^{-4}$ & $1.06 * 10^{-4}$ & - \\
Effective Young's modulus & $\mathrm{kPa}$ & 22000 & 20000 & 2200 & 25000 & $1.0^{*} 10^{6}$ \\
Effective Poisson's ratio & - & 0.3 & 0.3 & 0.35 & 0.29 & 0.2 \\
Effective cohesion & $\mathrm{kPa}$ & 5 & 1.5 & 14 & 33 & - \\
Effective friction angle & $\mathrm{deg}$ & 25 & 30 & 10 & 15 & - \\
\hline
\end{tabular}

Geosynthetic

Tensile elastic modulus: $86 \mathrm{KN} / \mathrm{m}$

\section{NUMERICAL RESULTS}

\section{A. Settlement Analysis}

The settlements of the embankment are examined under these four different cases and the comparative results of the finite element analysis are presented in Fig. III and Fig. IV. As shown in Fig. III, the variation of settlement at the embankment crest about 200 days after construction are presented. As can be seen, the settlements of the two piles without caps supported embankment cases (G1P1 case and G2P1 case) are obvious larger than the other two caped piles supported embankment cases (G1P2 case and G2P2 case). Withother cases unchanged, the pile supported embankment with the geosynthetic reduces the settlement compared with the embankment without geosynthetic, but the effect is not obvious. And the fluctuation ranges of the variations with the geosynthetic are smaller than the variations without the geosynthetic and the effect is more obvious compared with these two caped piles cases. Especially the settlement is nearly the same from $-8 \mathrm{~m}$ to $8 \mathrm{~m}$ around the center line of the embankment in G2P2 case.

Fig. IV shows that the differential settlement (difference between the maximum settlement and the minimum settlement) at the embankment crest increases with time changing after the construction. The differential settlement of G1P1 case is the larger than the others, followed by G1P2 case, then G2P1 case, and G2P2 case is the smallest of all. At the end of construction, the settlement in G1P2 case, G2P1 case and G2P2 case is $80.6 \%, 73.9 \%$ and $55.8 \%$, respectively, of the value in G1P1 case. The differential settlements more or less stabilizeabout 
100 days after construction. Thus, the geosynthetic and the pile caps can significantly reduce the differential settlement respectively, which is different from the effect of settlement (Fig. III), demonstrating that the effect of geosynthetic is very important in reducing the differential settlements and is more significant than that of pile caps.

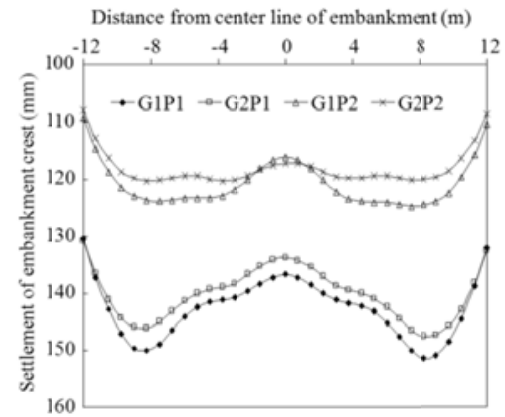

FIGURE III. SETTLEMENTS AT THE EMBANKMENT CREST

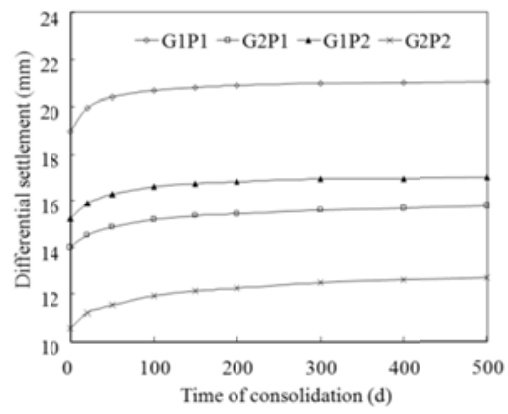

FIGURE IV. DIFFERENTIAL SETTLEMENT WITH TIME

\section{B. Lateral Displacement Analysis}

Fig. $\mathrm{V}$ displays the curves of the lateral displacement with the increasing depthbeneath point $\mathrm{C}$ of these four cases. It is clear that the lateral displacement slightlyincrease first in shallow depththen decrease significantly in the deep depth.The resultsshow that the geosynthetic almost has no effect on the lateral displacement. In the shallow depth, pile caps can significantly limit the lateral displacement, but with the increase of the depth, the effect of the pile caps decrease gradually. And all the variations of the lateral displacement are generally the same in firm soil.

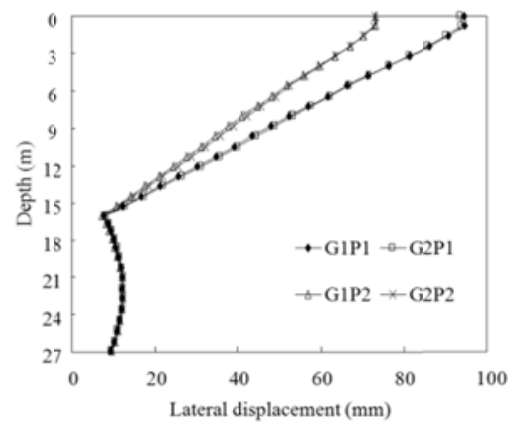

FIGURE V. VARIATION OF LATERAL DISPLACEMENT WITH DEPTH

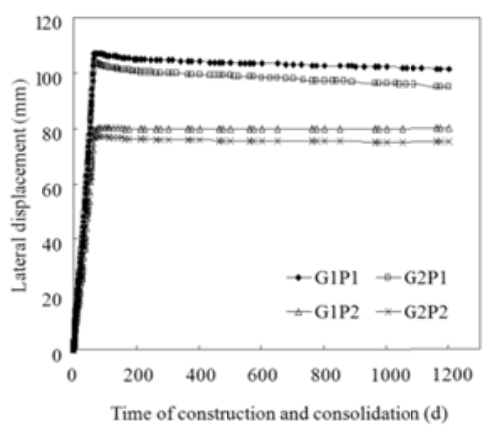

FIGURE VI. Variation of lateral displacement with time

As shown in Fig.VI, the variations of the lateral displacement at the embankment toe with time changing are presented. Theincrease in the lateraldisplacement is almost linear during embankmentfilling. In these four cases, the lateral displacement of G1P1 case is the largest of all, followed by G2P1 case, then G1P2 case and G2P2 case is the smallest. The values of the lateral displacement of the cases without the pile cap gradual decrease after construction, which are not stable at the 1000 days after construction. In contrast, the other two cases are stable after construction. At the 1000 days after construction, the value of the lateral displacement in G1P1 case is $10.14 \mathrm{~cm}, \mathrm{G} 2 \mathrm{P} 1$ case, G1P2 case and G2P2 case is $93.8 \%$, $78.7 \%$ and $74.2 \%$, respectively, of the value for G1P1 case. The results show that the effect of the geosynthetic is limited and the pile cap can significantly reduce the lateral displacement.

\section{Stress Analysis}

Fig. VII shows the variation of theaxial stress in the piles (point A) during theprocess of the filling in these four cases. When the embankment height is $1 \mathrm{~m}$, stress at the point A are basic the same in the two cases with pile caps and the other two cases without pile caps, respectively. The stresses of the two cases with pile cap are larger than the other two cases. With anincrease in the embankment height, the effect of the pile cap and the geosynthetic are gradually bringing into play. At the end of the filling, the stress in G1P1 case, G2P1 case, G1P2 case and G2P2 case is $730.16 \mathrm{kPa}, 788.83 \mathrm{kPa}, 840.65 \mathrm{kPa}$ and $874.42 \mathrm{kPa}$, respectively. In the two cases without the pile cap, the stress in the case reinforced by the piles combined with the geosynthetic increased by 8\% compared with the case reinforced by piles only, and in those two cases with the pile caps, G2P2 case increased by 4\%. Compared G1P1 case with G1P2 case, the stress in G1P2 case increased by $15 \%$ when used pile caps. As discussed above, the geosynthetic and the pile cap can transfer more embankment load to the piles, respectively. The effect of this transferring load of the pile caps is larger than the geosynthetic, and the effect of geosynthetic weakened as the case with the pile caps.

As shown in Fig. VIII, the variation of the pile-soil stress ratio ( $n=\sigma A / \sigma B, \sigma A$ is the value of the stress at point $A$ and $\sigma \mathrm{B}$ is the value of the stress at point $\mathrm{B}$ ) with an increase in the embankment height are presented. The ratio in the four casesis increasing significantly and the effect of the geosynthetic and the pile cap are bringing into play gradually with the increasing embankment height. At the end of filling, the maximum ratio of 
the four cases is G2P2 case, is 31.5, and G1P1 case, G2P1 case and G1P2 case is $61.2 \%, 71.6 \%$ and $88.1 \%$, respectively, of the value in G2P2 case. It is clear that the geosynthetic and the pile caps can improve the pile-soil stress ratio, and the effect of pile caps is larger than the geosynthetic.

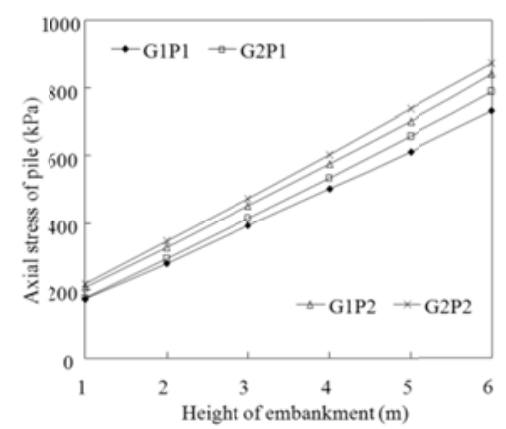

FIGURE VII. AXIAL STRESS OF PILE WITH EMBANKMENT HEIGHT

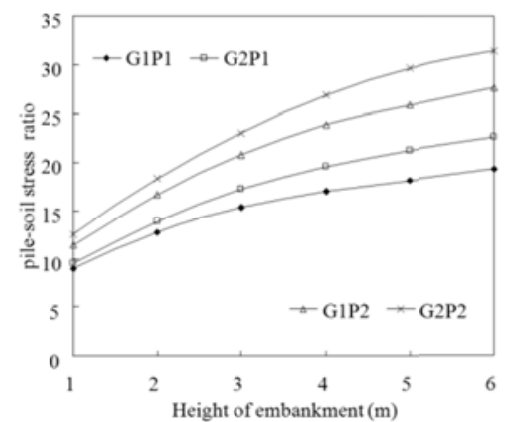

FIGURE VIII. PILE-SOIL STRESS RATIO WITH EMBANKMENT HEIGHT

\section{CONCLUSIONS}

In this paper, to optimization design of pile supported embankment, the numerical analysis was conducted to investigate the performance of four different cases of pile supported embankment. From this study, the following conclusions can be drawn:

(1) The pile cap and geosynthetic can reduce the settlement, but the effect of geosynthetic is not obvious. However, the effect of geosynthetic is very important in reducing the differential settlements and is more significant than that of pile caps.

(2) In the shallow depth, pile caps can significantly limit the lateral displacement, but with the increase of the depth, the effect of the pile caps decrease gradually. However, the influence on lateral displacement of geosynthetic is limited.

(3) The effect of this transferring load of the pile caps is larger than the geosynthetic, and the effect of pile caps is larger than the geosynthetic. Moreover, the effect of geosynthetic will be weakened as the case with the pile caps.

\section{ACKNOWLEDGMENTS}

This study was supported by the Basic Research Plan Projects in Shanxi Province (No. 2014021033-1). The authors would like to express the gratitude to the financial assistance.

\section{REFERENCES}

[1] Abusharar S W, Zheng J J and Chen B G. Finite element modeling of the consolidation behavior of multi-column supported road embankment. Computers and Geotechnics, 2009, 36(4), 676-685.

[2] Giroud J P, Bonaparte R, Beech J F, et al. Desigh of soil layergeosynthetic system overlying voids. Geotextiles and Geomenbrance, 1990, 9(1):11-50.

[3] Chen Y M, Jia N, Chen R P. Soil arch analysis of pile-supported embankments. China Journal of Highway and Transport, 2004, 17(4):1-6.

[4] Chew S H and Phoon H L. Geotextile reinforced piled embankment: fullscale model tests. Proceeding of the 3rd Asian Regional Conference on Geosynthetics. Seoul: Hotel Seoul Education and Culture Center, 2004: 661-668.

[5] Han J and GabrMA. A numerical study of load transfer mechanisms ingeosynthetic reinforced and pile supported embankments over soft soil. Journalof Geotechnical and Geoenvironmental Engineering, 2002, 128(1): 44-53.

[6]Zheng J J, Chen B G and Abusharar S W. The performance of an embankment on soft ground reinforced with geosynthetics and pile walls. Geosynthetics International, 2009, 16(3): 171-181.

[7] Lian F, Gong X N, Cui S C, et al. Field study of bearing behavior of pilenet composite foundation. Rock and Soil Mechanics, 2009, 30(4): 10571062. 